\title{
STRUKTUR KOMUNITAS DAN PERSENTASE TUTUPAN LAMUN DI MARINE FIELD STATION UNIVERSITAS SAM RATULANGI
}

\author{
(Community Structure And Seagrass Percent Cover at Marine Field Station \\ Sam Ratulangi University)
}

\author{
Anastasia V. Senduk ${ }^{{ }^{*}}$, Joshian N. W. Schaduw ${ }^{2}$, Veibe Warouw ${ }^{2}$, Billy Th. Wagey ${ }^{2}$, \\ Joice R.T.S.L. Rimper ${ }^{2}$, Anneke V. Lohoo ${ }^{3}$
}

1. Mahasiswa Program Studi IImu Kelautan, FPIK UNSRAT Manado

2. Dosen Program Studi IImu Kelautan

3. Dosen Program Studi Manejemen Sumberdaya Perairan, FPIK UNSRAT.

Penulis korespondesi: Anastasia V. Senduk; sendukanastasia@gmail.com

\begin{abstract}
In the world there are 60 species of seagrass, and 12 types are found in Indonesia. This study aims to determine the results of the description of the community structure and the percentage cover of seagrass in the waters of the Marine Fields Station, observations were made at 2 (ST.1 \& ST.2) stations using themethod seagrass watch and the results of data analysis of the community structure using the equation formula from Cox, 1967. In the waters of the Marine Fields Station, there are 6 species, namely Enhalus acoroides, Thalassia hemprichii, Cymodocea rotundata, Syringodium isoetifolium, Halodule pinifolia, and Halophile ovalis. The results of the percentage of seagrass cover at ST.1 were $58.85 \%$ and ST.2 $53.13 \%$ and the average value obtained from these 2 stations was $55.99 \%$. Overall, the community structure of ST.1 species Thalassia hemprichii has the highest important value index of $80.66 \%$. And in ST.2 Syringodium isoetifolium which has the highest important value index is $93.27 \%$. Parameters in the waters of Maine Field Station, namely $\mathrm{pH}$, salinity, temperature, substrate are good.
\end{abstract}

Keywords: Seagrass, Percentage Cover, Community Structure

\begin{abstract}
ABSTRAK
Di dunia terdapat 60 jenis lamun, dan 12 jenisnya terdapat di Indonesia. Dalam penelitian ini bertujuan untuk mengetahui hasil gambaran struktur komunitas dan tutupan persentase lamun di perairan Marine Fields Station, pengamatan dilakukan pada 2 (ST.1 \& ST.2) stasiun dengan menggunakan metode seagrass watch dan hasil analisis data dari struktur komunitas menggunakan rumus persamaan dari Cox, 1967. Di perairan Marine Fields Station terdapat 6 jenis yaitu Enhalus acoroides, Thalassia hemprichii, Cymodocea rotundata, Syringodium isoetifolium, Halodule pinifolia, Halophile ovalis. Hasil tutupan persentase lamun pada ST.1 58,85\% dan ST.2 53,13\% dan nilai rata-rata yang diperoleh dari ke 2 stasiun ini yaitu 55,99\%. Secara keseluruhan struktur komunitas dari ST.1 jenis Thalassia hemprichii memiliki indeks nilai penting tertinggi yaitu $80,66 \%$. Dan pada ST.2 jenis Syringodium isoetifolium yang memiliki indeks nilai penting tertinggi yaitu sebanyak 93,27\%. Parameter di perairan Maine Field Station yaitu $\mathrm{pH}$, salinitas, suhu, substrat tergolong baik.
\end{abstract}

Kata kunci: Lamun, Tutupan Persentase, Struktur komunitas. 


\section{PENDAHULUAN}

Indonesia merupakan negara yang terletak di garis khatulistiwa yang memiliki keanekaragaman hayati yang tinggi, sehingga memiliki garis pantai yang luas yang tercatat sepanjang $95.161 \mathrm{~km}$ (Lasabuda, 2013). Ekosistem padang lamun merupakan ekosistem pesisir sebagai tempat vegetasi yang dominan serta mampu bertahan hidup secara permanen di bawah permukaan air laut (Sheppard et al, 1996; Tangke 2010). Lamun merupakan tumbuhan berbunga yang hidupnya menyesuaikan diri dengan terbenam di laut dikarenakan lamun di temukan pada tempat yang terjadinya pasang surut.

Habitat lamun bisa dilihat sebagai suatu komunitas, karena padang lamun tergolong sebagai kerangka struktur yang berkaitan erat dengan hewan dan tumbuhan, karena tempat yang paling produktif sehingga bisa mendukung potensi sumberdaya yang tinggi pula (Azkab, 2001). Padang lamun juga bisa menjadi faktor utama dalam mendaur zat hara maupun elemen-elemen yang terdapat pada lingkungan laut. Selain tumbuhan bakau lamun juga bisa menyerap karbondioksida $\left(\mathrm{CO}_{2}\right)$ (Sjafrie dkk. 2018).

Berikut merupakan Morfoligi dari 5 jenis lamun yaitu :

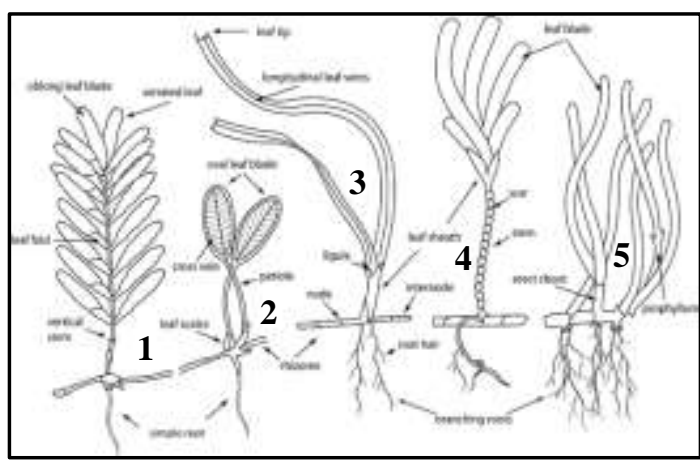

Gambar 1. Halophila Spinulosa (1), Halophila decipiens (2), Halodule uninervis (3), Thalassodendron ciliatum (4), Halodule uninervis (5). (Sumber

https://www.seagrasswatch.org/wpcon tent/uploads/images/seagrass_parts.g if).

Berikut penjelasan morfologi lamun : a. Akar : Fungsi akar lamun yaitu sebagai tempat menyimpan oksigen untuk berfotosintesis juga tempat untuk melakukan metabolisme aktif, maka konsentrasi dari $\mathrm{CO}_{2}$ di jaringan akar cenderung lebih tinggi (Phillips dan Meñez, 1988; Anonimous, 2008). b, Batang dan Rhizoma : Rhizome secara bersamaan menancapkan diri pada substrat dengan kokoh di dasar air secara horizontal dan setiap ronggarongga ditumbuhi batang-batang pendek. Tempat tumbuhnya daun pada lamun disebut node dan sebutan jarak node dengan yang lain disebut Internode (Wagey, 2013). c. Daun : Ada dua bagian berbeda yang terdapat pada daun lamun yaitu pelepah dan daun. Pelepah sebagai tempat pendudukan daun pada batang lamun. Tapi lamun dengan genus Halophila tidak terdapat pelapa. Bentuk pertumbuhan lamun bersifat monopodial teknik untuk membedakan setiap jenis lamun dapat diamati dari bentuk daun dan puncak daun (Wagey, 2013). 
Terdapat beberapa faktor pembatas untuk pertumbuhan lamun yang seperti suhu yang merupakan salah satu faktor penting dalam kelangsungan hidup biota di perairan karena memiliki pengaruh besar terhadap metabolisme maupun perkembangbiakan dari tiap organisme yang hidup di padang lamun. $\mathrm{pH}$ untuk tumbuhan lamun yaitu berkisar 7,8-8,5 karena pada kisaran tersebut ion bikarbonat yang diperlukan untuk proses fotosintesis oleh lamun dalam kondisi yang berlimpah. Substrat Faktor penting dari kedalaman substrat dalam stabilitas sedimen, mencakup 2 hal, yaitu proteksi tumbuhan dari arus laut serta sebagai tempat pengolahan dan sebagai pemasok nutrient (Wagey, 2013).

\section{METODE PENELITIAN}

\section{Lokasi Penelitian}

Penelitian ini dilakukan di Marine Field Station, Likupang Timur dan terdapat 2 titik stasiun pengamatan. Titik koordinat stasiun pengambilan data dapat dilihat pada tabel 1 , dan peta lokasi penelitian bisa dilihat pada gambar 2.

Tabel.1 Titik Koordinat Lokasi Penelitian

\begin{tabular}{|c|l|c|c|}
\hline \multirow{2}{*}{$\begin{array}{c}\text { No } \\
\cdot\end{array}$} & \multirow{2}{*}{\begin{tabular}{l} 
Stasiu \\
\cline { 3 - 4 }
\end{tabular}} & $\begin{array}{c}\text { Lintang } \\
\text { Utara }\end{array}$ & $\begin{array}{c}\text { Lintang } \\
\text { Timur }\end{array}$ \\
\hline 1. & ST 1 & $01^{\circ} 40^{\prime} 31.7^{\prime \prime}$ & $\begin{array}{c}125^{\circ} 04^{\prime} \\
30.4^{\prime \prime}\end{array}$ \\
\hline 2. & ST 2 & $01^{\circ} 40^{\prime} 35.0^{\prime \prime}$ & $\begin{array}{c}125^{\circ} 04^{\prime} \\
31.6^{\prime \prime}\end{array}$ \\
\hline
\end{tabular}

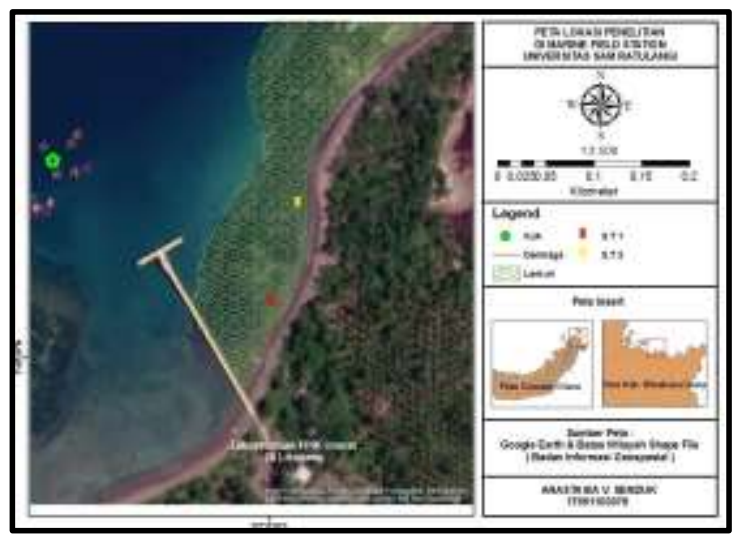

Gambar 2. Peta Lokasi Penelitian

\section{Seagrass watch}

Seagrass Watch dikembangkan oleh Northern Fisheries Centre, Australia yang diperuntukkan bagi masyarakat umum ataupun sukarelawan yang memiliki keinginan untuk melakukan monitoring padang lamun (McKenzie, 2003 ; ; Rahmawati dkk. 2017). Dengan metode seagrass watch sangat mempermudah untuk mendapatkan hasil data observasi lapangan dengan melibatkan banyak lembaga penelitian maupun organisasi non-pemerintah.

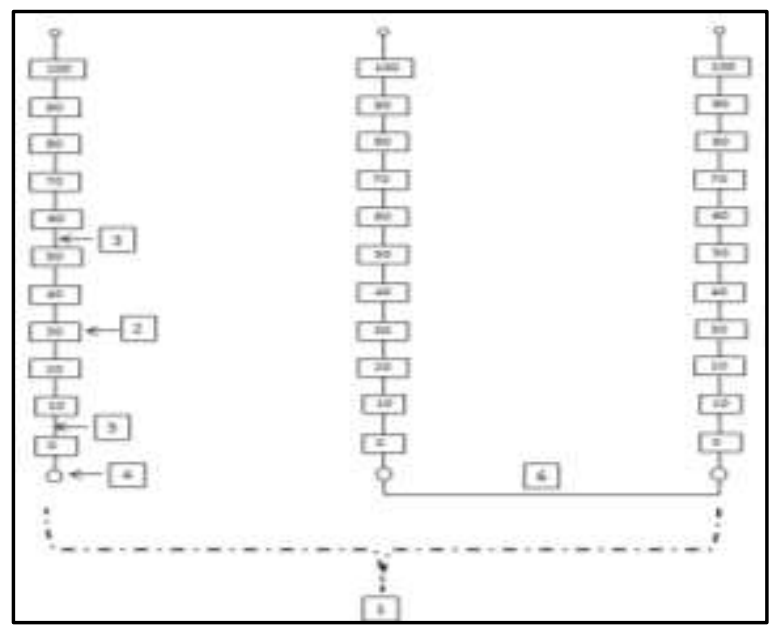

Gambar 3. Sketsa peletakan line transek kuadran di padang lamun.

Keterangan : 1. Garis pantai 2. Frame kudrat $50 \times 50 \mathrm{~cm}$ 3. Jarak antar 
frame kuadrat $10 \mathrm{~m} \mathrm{4}$. Titik utama line transek 5. Line transek 6 . Jarak per garis transek $50 \mathrm{~m}$

Pengamatan nilai persentase tutupan lamun pada setiap kotak kecil yang terdapat pada kuadrat frame berdasarkan penilaian pada tabel di bawah ini.

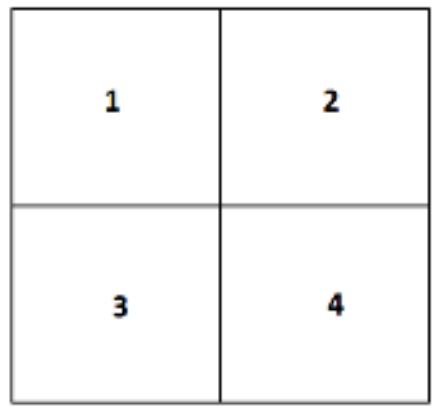

Gambar 4. Frame kuadrat $50 \mathrm{~cm} \mathrm{x}$ $50 \mathrm{~cm}$

\section{Tabel 2. Penilaian dominasi tutupan lamun}

Pengamatan Parameter Lingkungan

a. Suhu

Pengukuran suhu menggunakan thermometer yang dilakukan di tiap 3 line transek per stasiun. Pengamatan suhu yaitu dengan dicelupkan thermometer kedalam air, hindari untuk mengangkat thermometer ke permukaan perairan karena bisa menyebabkan perubahan angka suhu dari kolom perairan dan permukaan air.

b. Derajat Keasaman pH

Pengukuran $\mathrm{pH}$ menggunakan kertas lakmus yang diambil di tiap line transek dengan cara mencelupkan kertas lakmus kedalam perairan dan warna akan muncul kemudian mencocokan warna standar $\mathrm{pH}$ yang memiliki nilai baku.

\section{c. Substrat}

Pengamatan substrat dilakukan secara visual di tiap kuadran. Biasanya terdapat jenis seperti pasir berlumpur atau pasir dari pecahan karang.

d. Salinitas

Pengukuran salinitas yaitu dengan menggunakan refraktometer. Yaitu dengan mengambil sampel air laut di tiap titik stasiun dan teteskan pada kaca prisma.

\section{Analisis Data}

Berikut merupakan rumus perhitungan yang digunakan untuk menentukan nilai tutupan persentase lamun :

a. Rata-rata penutupan lamun (\%)= jlh penutupan lamun seluruh transek jlh kuadrat transek

b. Rata-rata penutupan lamun (\%)= jlh penutupan lamun seluruh transek jlh kuadrat transek

Adapun persamaan rumus

\begin{tabular}{|l|c|}
\hline \multicolumn{1}{|c|}{ Kategori } & $\begin{array}{c}\text { Nilai Penutupan } \\
\text { Jenis Lamun }\end{array}$ \\
\hline Tutupan Penuh & $100 \%$ \\
\hline Tutupan $3 / 4$ kotak kecil & $75 \%$ \\
\hline Tutupan $1 / 2$ kotak kecil & $50 \%$ \\
\hline Tutupan $1 / 4$ kotak kecil & $25 \%$ \\
\hline Kosong & $0 \%$ \\
\hline
\end{tabular}

untuk menganalisis data yang mendapatkan kepadatan spesies di lokasi penelitian (Cox, 1967 ; Sara et al. 2020) :

Kepadatan spesies

$$
=\frac{\text { jumlah individu tiap jenis }}{\text { Luas wilayah contoh }\left(\mathrm{m}^{2}\right)}
$$

Kepadatan relatif (\%)

$$
=\frac{\text { jumlah individu tiap jenis }}{\text { Jumlah individu seluruh spesies }}
$$




$$
\begin{gathered}
\text { Dominasi }=\frac{\text { luas tutupan }}{\text { luas wilayah }} \\
=\frac{\text { dominasi untuk satu spesies }}{\text { dominasi total untuk semua spesies }} \\
\times 100
\end{gathered}
$$

Frekuensi

$=\frac{\text { jumlah kuadrat ditemukaanya satu spesies }}{\text { Jumlah seluruh kuadrat }}$

$$
\begin{gathered}
\text { Frekuensi relatif (\%) } \\
=\frac{\text { frekuensi dari satu jenis }}{\text { frekuensi seluruh jenis }} \times 100
\end{gathered}
$$

Indeks Nilai Penting =

Kepadatan Relatif + Dominasi Relatif

+ Frekuensi Relatif

Indeks Dominasi

$$
D=\sum_{i=1}^{s}\left[\frac{n i}{N}\right]^{2}
$$

Keterangan :

$\mathrm{D}=$ indeks dominansi

$\mathrm{ni}=$ jumlah individu jenis ke-i

$\mathrm{N}=$ total jumlah individu

Indeks dominasi antara 0 dan 1, apa bila $D$ mendekati angka 0 , maka hasilnya menunjukan tidak terjadi dominasi dan struktur komunitas dalam keadaan stabil dan sebaliknya apabila $D$ mendekati 1 menunjukkan terjadi dominasi dari spesies tertentu.
Indeks Keragaman Jenis (H')

$$
D=\sum_{i=1}^{s} \frac{n i}{N}\left(\operatorname{In} \frac{n i}{N}\right)
$$

Keterangan :

$\mathrm{H}=$ Indeks Keanekaragaman Shannon-

Wiener

$\mathrm{ni}=$ Jumlah individu jenis ke-i

$\mathrm{N}=$ Jumlah total individu

$S=$ Jumlah genera

Indeks Shannon-Wiener memiliki indikator sebagai berikut :

$\mathrm{H}^{\prime}<1.5=$ tingkat keanekaragaman rendah, $1.5 \leq \mathrm{H}^{\prime} \geq 3.5=$ tingkat keanekaragaman sedang, $\mathrm{H}^{\prime}>3.5=$ tingkat keanekaragaman tinggi

\section{HASIL DAN PEMBAHASAN}

\section{Deskripsi Spesies Lamun}

Hasil pengamatan lapangan terdapat 6 jenis lamun, yaitu Enhalus acoroides, Thalassia Hemprichii, Cymodocea rotundata, Syringodium isoetifolium, Halodule Pinifolia, Halophila ovalis. Berikut gambar dan deskripsi dari tiap-tiap jenis ;

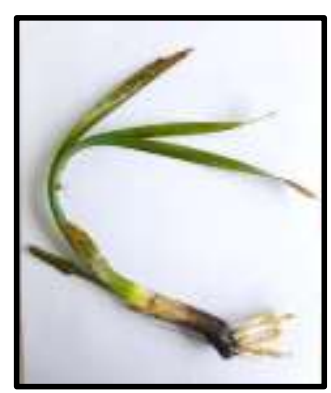

Gambar 5. Enhalus acoroides

Enhalus acoroides merupakan jenis lamun yang ukuran morfologinya besar. Pada rhizomanya terdapat rembut-rambut hitam dan juga memiliki akar yang banyak. Tumbuhan ini kebanyakan tumbuh 
pada substrat pasir, pasir berlumpur dan pasir pecahan karang dan ujung daunnya bergerigi.

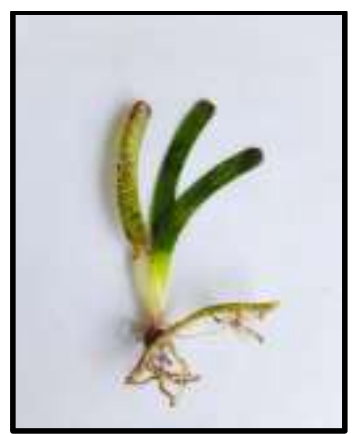

Gambar 6. Thalassia Hemprichii

Thalassia Hemprichii memiliki ujung daun yang berbentuk setengah lingkaran. Memiliki kemiripan seperti Cymodocea rotundata tapi pada rhizoma terdapat ruas-ruas dan tebal dan terdapat bercak-bercak coklat tiap helaian daun.

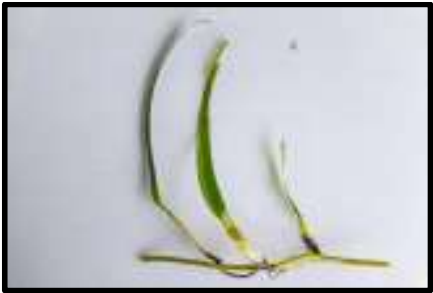

Gambar 7. Cymodocea rotundata

Dapat dilihat jenis lamun ini memiliki helaian daun yang lurus dan tidak bergerigi dan seludang daun tertutup sempurna dan ujung daun seperti berbentuk huruf $m$. Jenis ini sering ditemukan pada substrat pasir pecahan karang.

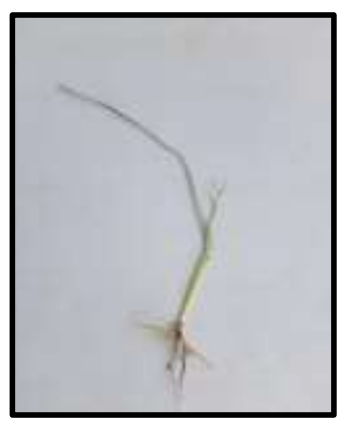

Gambar 8. Syringodium isoetifolium

Syringodium isoetifolium memiliki bentuk daun yang silindris dan ujung daunnya runcing, helaian daun tumbuh dari rhizome yang halus. Jenis ini bisa dijumpai pada substrat pasir pecahan karang dan pasir berlumpur.

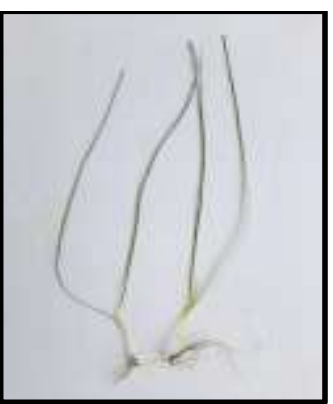

Gambar 9. Halodule Pinifolia

Ciri khusus Halodule Pinifolia memiliki daun pipih yang panjang tapi berukuran kecil, ujung daun agak membulat, rhizome halus dengan bekas daun menghitam. 


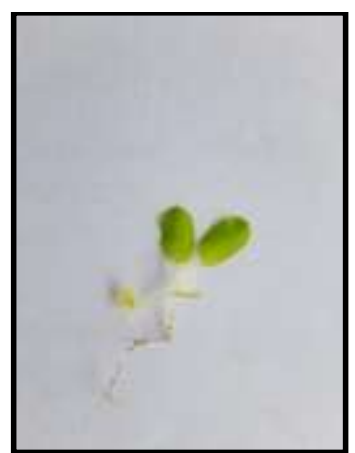

Gambar 10. Halophila ovalis

Halophila ovalis memiliki daun oval, berpasangan dengan tangkai pada tiap ruas dari rimpang, memiliki 8 tulang daun atau lebih. Jenis ini bisa ditemui pada substrat pasir pecahan karang dan pasir berlumpur.

\section{Hasil Analisis Data Tutupan Persentase}

Dengan hasil pengolahan data tutupan perentase di perairan Marine Field Station yang di lakukan pada dua titik stasiun (ST.1 dan ST.2) termasuk pada kategori kurang sehat, berdasarkan penilaian yang di putuskan oleh menteri lingkungan hidup No. 200/ 2004

Tabel 3 Kategori status padang lamun keputusan menteri lingkungan hidup No. 200/ 2004

\begin{tabular}{|c|c|c|}
\hline \multicolumn{2}{|c|}{ Kondisi } & Penutupan (\%) \\
\hline Baik & Kaya / Sehat & $\geq 60$ \\
\hline \multirow{2}{*}{ Rusak } & $\begin{array}{c}\text { Kurang Kaya / } \\
\text { Kurang Sehat }\end{array}$ & $30-59,9$ \\
\cline { 2 - 3 } & Miskin & $\leq 29,9$ \\
\hline
\end{tabular}

Berikut merupakan hasil ratarata tutupan persentase lamun yang diperoleh dari ST.1 dan ST.2

Tabel. 5 Rata-rata Tutupan Lamun Per Lokasi

\begin{tabular}{cc}
\hline Lokasi & $\begin{array}{c}\text { Rata-rata Penutupan } \\
\text { Lamun (\%) }\end{array}$ \\
\hline ST 1 & 58,85 \\
\hline ST 2 & 53,13 \\
\hline Rata-rata & 55,99 \\
\hline Stdev & 4,05 \\
\hline
\end{tabular}

Adapun hasil pengolahan data tutupan lamun per jenis dari ST.1 dan ST.2 berikut merupakan grafik dari tutupan lamun perjenis.

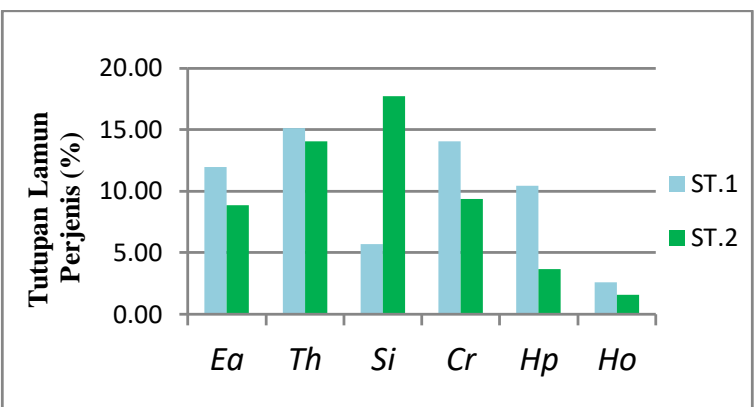

Gambar 11. Grafik tutupan lamun per jenis dari ST.1 dan ST.2

Pada ST.1 terdapat nilai persentase tertinggi dari jenis Thalassia hemprichii 15,10\%, Cymodocea rotundata 14,06\%, Halodule pinifolia $10,42 \%$, Enhalus acoroides $11,98 \%$, Syringodium isoetifolium 5,68 \%, Halophila ovalis $2,6 \%$. Dan pada ST.2 jenis yang memiliki nilai tutupan tertinggi yaitu Syringodium isoetifolium $17,71 \%$ dan Thalassia hemprichii 14,06\%, Cymodocea rotundata 9,38\%, \%, Halodule pinifolia $3,65 \%$, Enhalus acoroides $8,85 \%$, Halophila ovalis $1,56 \%$ Pada hasil analisis data tersebut tiap jenis yang memiliki nilai tertinggi bisa dikatakan bahwa merupakan jenis perintis di titik tersebut (Hidayat et al. 2014 ; Schaduw \& Kondoy 2020). Tutupan lamun perjenis yang dilansir pada penelitian dari Schaduw \& Kondoy pada tahun 2020 yang dilakukan pada 
5 pulau kecil (Bunaken, siladen, Manado Tua, Mantehage, dan Nain) di ST.1 terdapat 2 dari 5 pulau yang memiliki tutupan lamun per jenis yang sama yaitu dari jenis Thalassia hemprichii. Jenis ini memiliki nilai tutupan tertinggi yaitu di pulau Siladen dan Manado Tua. Sedangkan pada ST.2 tidak menunjukan adanya nilai tutupan yang sama.

\section{Hasil Analisis Data Kepadatan Relatif ST.1 dan ST.2}

Berikut merupakan grafik dari hasil analisis dari kepadatan relatif yang dilakukan pada ST.1 dan ST.2, terdapat hasil yang beragam di kedua stasiun ini.

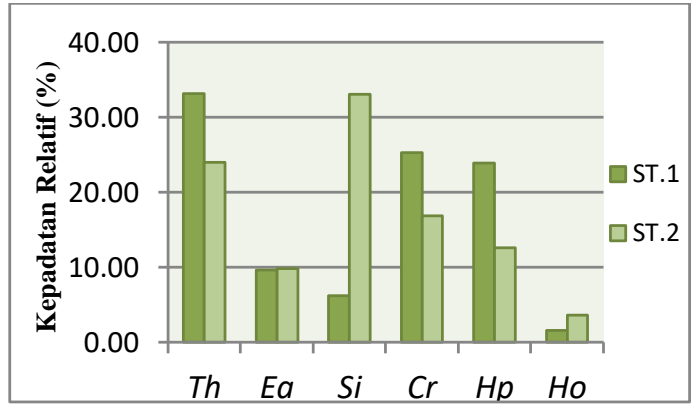

Gambar 12. Grafik Kepadatan Relatif ST.1 dan ST.2

Pada stasiun ST.1 bisa di lihat terdapat nilai kepadatan yang bervariasi dari tiap jenis. Terdapat 3 jenis lamun yang memiliki kepadatan tinggi yaitu dari jenis Thalassia hemprichii $33,20 \%$, Cymodocea rotundata 25,35\%, dan Halodule pinifolia 23,94\%, Enhalus acoroides $9,66 \%$, Syringodium isoetifolium 6,24 $\%$, Halophila ovalis 1,61 \%. Berdasarkan hasil perhitungan kepadatan jenis pada ST.2 dengan perolehan hasil paling tinggi yaitu pada jenis Syringodium isoetifolium $33,07 \%$ dibandingkan dengan jenis lamun yang lain yaitu Thalassia hemprichii 24,05\%, Cymodocea rotundata 16,83\%, Halodule pinifolia
12,63\%, Enhalus acoroides 9,82 \%, dan Halophila ovalis 3,61\%.

Berdasarkan hasil kepadatan relatif tersebut bisa dilihat pada ST.1 yang memiliki nilai kepadatan relatif terbanyak yaitu dari jenis Thalassia hemprichii karena pada stasiun ini memiliki substrat pasir berlumpur yang merupakan tempat pertumbuhan dari jenis Thalassia hemprichii. Pada ST.2 terdapat jenis Syringodium isoetifolium yang memiliki nilai tertinggi pada hasil analisis di stasiun ini, jenis tersebut sering dijumpai pada stasiun ini karena terdapat substrat pasir bercampur pecahan karang.

\section{Hasil Analisis Data Dominasi Relatif ST.1 dan ST.2}

Adapun hasil analisis data dari dominasi relatif dari dua titik stasiun yaitu dari ST.1 dan ST.2. Berikut pembahasan dominasi relatifnya.

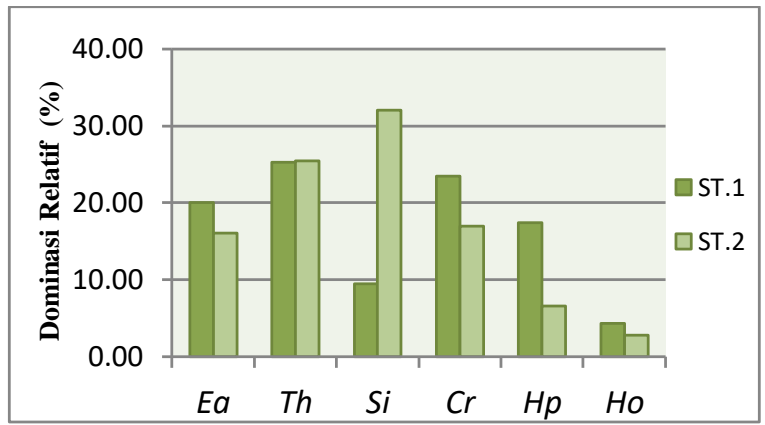

Gambar 13. Grafik Dominasi Relatif ST.1 dan ST.2

Hasil dari dominasi dari ST.1 yang menunjukan hasil dominasi yang bervariasi, yang menunjukan bahwa Enhalus acoroides $20,02 \%$, Thalassia hemprichii 25,24 \%, Syringodium isoetifolium 9,49\%, Cymodocea rotundata $23,50 \%$, Halodule pinifolia $17,41 \%$, Halophila ovalis $4,35 \%$. Dominasi relatif di ST.2 dengan jenis lamun yang memperoleh nilai tertinggi yaitu jenis Syringodium isoetifolium 
$32,08 \%$ dibandingkan dengan dominasi relatif dari jenis lamun lainnya yaitu Thalassia hemprichii $25,47 \%$, Cymodoceae rotundata $16,98 \%$, Enhalus acoroides 16,04\%, Halodule pinifolia $6,60 \%$, Halophila ovalis $2,83 \%$.

\section{Hasil Analisis Data Frekuensi Relatif ST.1 dan ST.2}

Frekuensi Relatif merupakan perbandingan antara frekuensi spesies ke-I dan jumlah frekuensi untuk seluruh spesies. Berikut hasil analisis data dari frekuensi relatif di ST.1 dan ST.2.

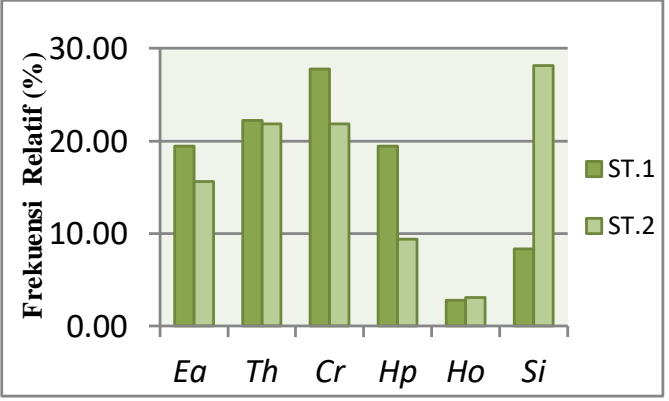

Gambar 14. Grafik Frekuensi Relatif ST.1 dan ST.2

Frekuensi relatif tertinggi pada ST.1 yaitu Cymodocea rotundata $27,78 \%$ yang mengindikasikan bahwa jenis ini sering dijumpai pada stasiun ini. Frekuensi relatif selanjutnya ada Enhalus acoroides 19,44\%, Thalassia hemprichii $22,22 \%$, Halodule pinifolia $19,44 \%$, Halophila ovalis $2,78 \%$, Syringodium isoetifolium $8,33 \%$. Frekuensi relatif paling tinggi yang diperoleh oleh ST.2 yaitu jenis lamun Syringodium isoetifolium $28,12 \%$ dibandingkan jumlah yang diperoleh dari jenis lain yaitu Halophila ovalis $3,12 \%$, Halodule pinifolia 9,37\%, Enhalus acoroides $15,63 \%$, Thalassia hemprichii $21.87 \%$, dan Cymodecea rotundata $21,87 \%$.

\section{Hasil Analisis Data Indeks Nilai Penting ST.1 dan ST.2}

Berikut adalah hasil analisis data indeks nilai penting dari ST.1 dan ST 2 (gambar 18). Pembahasan ini terdapat hasil yang bervariasi dari setiap stasiunnya.

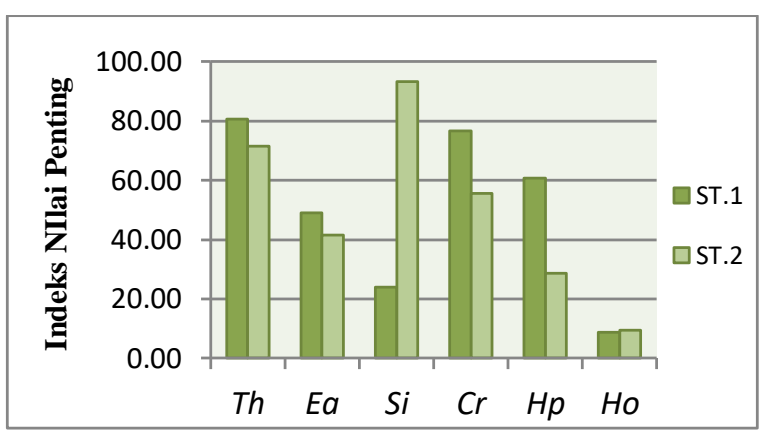

Gambar 20. Indeks Nilai Penting ST.1 dan ST.2

Indeks nilai penting lamun pada ST.1 menunjukan spesies Thalassia hemprichii mencapai $80,66 \%$, Cymodocea rotundata $76,63 \%$, Halodule pinifolia $60,79 \%$, Enhalus acoroides $49,12 \%$, Syringodium isoetifolium 24,06\%, Halophila ovalis $8,74 \%$. Berdasarkan perhitungan indeks nilai penting, spesies yang memiliki nilai penting yaitu dari spesies Thalassia hemprichii. Indeks nilai penting pada ST.2 dengan hasil tertinggi diperoleh pada jenis lamun Syringodium isoetifolium dengan jumlah $93,27 \%$. Dibandingkan dengan hasil indeks nilai penting dari jenis lamun lainnya yaitu Thalassia hemprichii 71,39\%, Halodule pinifolia $28,60 \%$, Cymodocea rotundata 55,69\%, Enhalus acoroides 41,48\%, Halophila ovalis $\quad 9,56 \%$. Berdasarkan perhitungan perhitungan indeks nilai 
penting, spesies yang memiliki nilai penting yaitu dari spesies Syringodium isoetifolium.

Indeks Dominasi Dan Indeks Keanekaragaman Dari ST.1 dan ST.2

Berikut merupakan tabel perbandingan indeks dominasi dan indeks keanekaragaman dari ST.1 dan ST.2 ;

\begin{tabular}{c|c|c|c}
\hline \multirow{2}{*}{$\begin{array}{c}\text { No } \\
\cdot\end{array}$} & \multirow{2}{*}{ Kategori } & \multicolumn{2}{|c}{ Nilai } \\
\cline { 3 - 4 } 1. & $\mathrm{D}$ & $\begin{array}{c}0,2452 \\
99\end{array}$ & ST.2 \\
\hline 2. & $\mathrm{H}^{\prime}$ & 1,5222389 & 1,618 \\
\hline
\end{tabular}

Tabel 6. Perbandingan Indeks Keanekaragaman dan Indeks Dominasi

Indeks dominasi yang mendekati angka nol menunjukan tidak adanya spesies yang mendominasi. Dan penilaian unutk indeks keanekaragaman berdasarkan indicator indeks Shannon-Wienner H' $<1.5=$ tingkat keanekaragaman rendah, $1.5 \leq \mathrm{H}^{\prime} \geq 3.5=$ tingkat keanekaragaman sedang, dan $\mathrm{H}^{\prime}>$ 3.5 = tingkat keanekaragaman tinggi. Berikut tabel hasil perbandingan dari Indeks Keanekaragaman dan indeks dominasi dari ST.1 dan ST.2

Berdasarkan tabel 6 indeks dominasi pada ST.1 mendapatkan hasil 0,2455299 dimana penilaian indeks dominasi menunjukan nilai yang mendekati nol menunjukan tidak adanya spesies yang mendominasi. Dan hasil yang didapatkan oleh ST.2 0,222389 dengan hasil tersebut menunjukan bahwa tidak ada jenis yang mendominasi pada stasiun ini. Untuk indeks keanekaraaman pada ST.1 termasuk kategori tingkat keanekaragaman sedang karena memperoleh nilai 1,522 begitupun dengan indeks keanekaragaman pada ST.2 yaitu memperoleh hasil 1,618 yang termasuk kategori tingkat keanekaragaman sedang.

\section{Hasil Pengukuran Parameter Lingkungan di Perairan Marine Field Station.}

Pengukuran parameter lingkungan menggunakan beberapa alat seperti thermometer untuk mengukur suhu, kertas lakmus untuk mengukur $\mathrm{pH}$, dan refraktometer untuk mengukur salinitas perairan. Secara lengkap hasil pengukuran parameter lingkungan di Perairan Marine Field Station terdapat pada tabel dibawah ini.

Tabel 7. Hasil Pengukuran Parameter Lingkungan di Perairan Marine Field Station.

\begin{tabular}{cc}
\hline $\begin{array}{c}\text { Parameter } \\
\text { lingkungan }\end{array}$ & hasil \\
\hline $\begin{array}{c}\text { Suhu }{ }^{\circ} \\
\text { Salinitas (\%) }\end{array}$ & $32^{\circ} \mathrm{C}$ \\
pH & $30(\%)$ \\
Substrat & $\begin{array}{c}\text { Lumpur berpasir, Pasir } \\
\text { berlumpur, dan pasir } \\
\text { bercampur pecahan } \\
\text { karanng }\end{array}$ \\
\hline
\end{tabular}

\section{KESIMPULAN}

Spesies lamun yang didapatkan pada tiap stasiun (ST.1 \& ST.2) di perairan Marine Field Station Universitas Sam Ratulangi terdapat ada 6 jenis dari 5 genus, yaitu; Enhalus acoroides, Thalassia Hemprichii, Cymodocea rotundata, Syringodium isoetifolium, Halodule Pinifolia, Halophila ovalis. Pada ST.1 tutupan rata-ratanya 
menghasilkan $58,85 \%$, dan pada ST.2 tutupan rata-ratanya adalah $53,13 \%$. Indeks nilai penting dari ST.1 yaitu dari jenis Thalassia Hemprichii $80,66 \%$, dan indeks nilai penting pada ST.2 Syringodium isoetifolium $92,27 \%$.

\section{UCAPAN TERIMA KASIH}

Penulis mengucapkan terima kasih kepada : Kementerian Pendidikan Kebudayaan Riset dan Teknologi melalui hibah penelitian terapan unggulan perguruan tinggi ; Lembaga Penelitian dan Pengabdian Pada Masyarakat Universitas Sam Ratulangi ; Fakultas Perikanan dan IImu Kelautan Universitas Sam Ratulangi ; Pemerintah Daerah Kabupaten Kabupaten Minahasa Utara ; Dinas Kelautan Perikanan dan Kelautan Provinsi Sulawesi Utara ; Penulis juga mengucapkan terima kasih kepada semua pihak yang terkait dalam riset ini.

\section{DAFTAR PUSTAKA}

Anonimous. 2008. "Pedoman Umum Identifikasi dan Monitoring Lamun". Departemen Kelautan dan Perikanan (DKP); Direktorat Konservasi dan Taman Nasional Laut. PT Bina Mitra Wahana. 86 hal.

Azkab, M. H. 2001. Peggunaan Inderaja Pada Padang Lamun. Oseana, XXVI(2): 9-16

Lasabuda R., 2013 "Pembangunan Wilayah Pesisir Dan Lautan Dalam Perspektif Negara Kepulauan Republik Indonesia", Jurnal IImiah Platax Vol. I-2.

McKenzie, L. J. 2003. Draft guidelines for the rapid assessment of seagrass habitats in the wester Pacific. QFS, NFC, Cairns. 43 pp.

Menteri Negara Lingkungan Hidup. Nomor : 200 Tahun 2004 Tentang Kriteria Baku Kerusakan Dan Pedoman Penentuan Status Padang Lamun

Phillips RC and Menez EG. 1988. Seagrasses. Smithsonian Contribution to the Marine Science no.34. Smithsonian Institutions Press Washington D.C

Rahmawati S., Irawan A., Supriyadi I, H., Azkab M, H,. 2017 "Panduan Pemantauan Penilaian Kondisi Padang Lamun" edisi 2. Coral reef information and training center (CRITC), Coral Reef Rehabilitation and Management Program (COREMAP), Puslit Oseanografi, Jl. Pasir putih No. 1. Indonesia. (1-24)

Sara A., Lalamentik L, Th. X., Rondonuwu A., 2020 "Struktur Komunitas Lamun (Seagrass) di Perairan Pantai Kelurahan Molas, Kecamatan Bunaken Kota Manado Sulawesi Utara." Jurnal IImiah Platax Vol. 7:(1), Januari-Juni 2020

Schaduw J. N. W., Kondoy K. F I., 2020"Seagrass percent cover in small islands of Bunaken National Park, North Sulawesi Province, Indonesia" AACL Bioflux, 2020, Volume 13, Issue 2. 
Seagrass-Watch Global Seagrass

Observing Network. 2020, Background (online)https://www.seagrasswatc h.org/seagrasswatch/. Diakses pada tanggal 15 Juli 2020, pada pukul 12.21 Wita.

Shepherd S.A., A.W.D. Larkum, A.J. McComb. (eds). 1966 "A treatles on the Biology of Seagrass with a Special reference to the Australian Region" University of California, ISBN 0444874038, 9780444874030.

Sjafrie N. D. M., Hermawan U. E. ., Prayudha B., Supriyadi I. H., Iswari M. Y. ., Rahmat, Anggraini K., Rahmawati S., Suyarso, 2018. "Status Padang Lamun Indonesia 2018 Ver.02", Puslit Oseanografi - LIPI, September 2018, JI. Pasir putih I, Ancol Timur, Jakarta Utara Indonesia Tangke U., 2010. " Ekosistem Padang Lamun (Manfaat, Fungsi dan Rehabilitasi)" vol 3 . Jurnal Ilmiah Agribisnis dan Perikanan. Edisi 1 hal. 12-13.

\footnotetext{
Wagey Billy 2013. "Hilamun (Seagrass)". Unsrat Press. Manado, Indonesia page 1-27
} 